\title{
Correction to: The Ratio of Mitochondrial DNA to Genomic DNA Copy Number in Cumulus Cell May Serve as a Biomarker of Embryo Quality in IVF Cycles
}

Seung Chel Yang ${ }^{1} \cdot$ Eun Jeong Yu ${ }^{2}$. Jae Kyun Park ${ }^{1,2} \cdot$ Tae Hyung Kim ${ }^{2} \cdot$ Jin Hee Eum ${ }^{2} \cdot$ Soo Kyung Paek ${ }^{2}$.

Ji Young Hwang ${ }^{2}$. Sang Woo Lyu ${ }^{2} \cdot$ Jin Young Kim ${ }^{2} \cdot$ Woo Sik Lee ${ }^{2} \cdot$ Tae Ki Yoon $^{3} \cdot$ Haengseok Song $^{1} \cdot$ Hee Jun Lee $^{2}$

Published online: 15 June 2021

(C) Society for Reproductive Investigation 2021

Correction to: Reproductive Science.

https://doi.org/10.1007/s43032-021-00532-3

This article was updated to correct errors in Tables 1 and 2.

Publisher's Note Springer Nature remains neutral with regard to jurisdictional claims in published maps and institutional affiliations.

Seung Chel Yang and Eun Jeong Yu contributed equally to this work. Haengseok Song and Hee Jun Lee contributed equally to this work.

The online version of the original article can be found at https://oi.org/ $10.1007 / \mathrm{s} 43032-021-00532-3$

Haengseok Song hssong@cha.ac.kr

$\triangle$ Hee Jun Lee alonfo@chamc.co.kr

1 Department of Biomedical Science, CHA University, Gyeonggi-do, Seongnam-si 13488, South Korea

2 Department of Obstetrics \& Gynecology, Fertility Center of CHA, Gangnam Medical Center, CHA University, Seoul, South Korea

3 CHA Fertility Center, Seoul Station, Seoul, South Korea 